\title{
Mannich reaction: A versatile and convenient approach to bioactive skeletons
}

\author{
SELVA GANESAN SUBRAMANIAPILLAI \\ School of Chemical and Biotechnology, SASTRA University, Thanjavur-613 401, India \\ e-mail: selva@biotech.sastra.edu
}

MS received 27 December 2011; revised 17 September 2012; accepted 6 December 2012

\begin{abstract}
This review gives an insight into the recent applications of Mannich reaction and its variants in the construction of bioactive molecules. Emphasis is given to the Mannich reaction that provides bioactive molecules and/or modifies the property of an existing bioactive molecule. The role of Mannich reaction in the construction of antimalarial, antitumour, antimicrobial, antitubercular, antiinflammatory and anticonvulsant molecules and also the significance of aminoalkyl Mannich side chain on the biological property of molecules is discussed here.
\end{abstract}

Keywords. Mannich reaction; Mannich bases; bioactive molecules; antimalarial; antitumour; antitubercular.

\section{Introduction}

The development of new drugs and target specific delivery agents with enhanced efficacy is essential to counter the multi-drug resistant (MDR) tumours ${ }^{1 \mathrm{a}, \mathrm{b}}$ and microbial strains. The modification of an existing drug molecules offers a cost and time effective convenient strategy to achieve new bioactive skeletons. Mannich reaction provides a suitable method to introduce aminoalkyl substituent into a molecule. ${ }^{1 c}$ In several instances, the Mannich derivatives exhibit better activity than the corresponding parent analogues vide infra. Moreover, the presence of Mannich side chain increases the solubility and hence the bioavailability of the drug molecule. This review surveys on the recent applications of multifaceted Mannich reaction in the synthesis of antimalarial, antitumour, antimicrobial, antitubercular, antiinflammatory and anticonvulsant molecules.

\subsection{Mannich reaction and its modern variants}

Mannich reaction ${ }^{2}$ is one of the most fundamental and important, $\mathrm{C}-\mathrm{C}$ bond forming reactions in organic synthesis. Mannich reaction withstands a large diversity of functional groups and hence it has been witnessing a continuous growth in the field of organic chemistry. The surge of literature on Mannich reaction provides an outstanding evidence for the diversity and applications of the reaction. ${ }^{3 \mathrm{a}-\mathrm{j}}$ The Mannich reaction and its variants offer a robust method for the preparation of the aminocarbonyl and several other derivatives. $^{4 \mathrm{a}-\mathrm{e}}$ The following scheme depicts the synthesis

$$
\begin{aligned}
& \mathrm{R}_{\mathrm{R}^{2}}^{\mathrm{O}}+{ }^{\mathrm{R}^{3}} \mathrm{~N}_{\mathrm{H}}^{-\mathrm{R}^{4}}+\mathrm{CH}_{2} \mathrm{O} \\
& \mathrm{R}^{1}, \mathrm{R}^{2}=\text { alkyl or aryl } \\
& \mathrm{R}^{3}, \mathrm{R}^{4}=\text { cyclic or acyclic amine }
\end{aligned}
$$

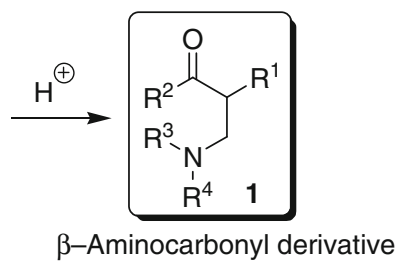

Scheme 1. Mannich reaction.

of $\beta$-aminocarbonyl compounds $\mathbf{1}$ by Mannich reaction (scheme 1).

However, the classical Mannich reaction has limitations such as lack of selectivity, competitive aldol reactions, etc. To overcome these limitations, modern variants of Mannich reaction utilize preformed imines, enolates, appropriate use of catalyst and reaction conditions, etc. ${ }^{3 \mathrm{a}-\mathrm{j}, 5 \mathrm{a}-\mathrm{f}}$ Several chiral auxiliaries and chiral catalysts are often employed to carry out asymmetric Mannich-type reaction. ${ }^{3 \mathrm{~b}, 6 \mathrm{a}-\mathrm{e}}$ Apart from this, basic nanocrystalline magnesium oxide, ${ }^{7 \mathrm{a}}$ recyclable copper nanoparticles, ${ }^{7 \mathrm{~b}}$ poly(amidoamine) catalysed reactions $^{7 \mathrm{c}}$ and microwave-assisted Mannich reactions ${ }^{7 \mathrm{~d}}$ have also been reported recently. Hayashi et al. discovered high pressure asymmetric Mannich-type reaction in frozen water medium. ${ }^{7 \mathrm{e}}$ Cimarelli et al. reported three component Mannich reaction under neat condition for the synthesis of diaminoalkylnaphthols. ${ }^{7 \mathrm{f}}$

\section{1a Proline/organocatalysed asymmetric Mannich-} type reaction: The proline/organocatalysed asymmetric Mannich-type reaction plays a seminal role in enantioselective and diastereoselective $\mathrm{C}-\mathrm{C}$ bond forming 


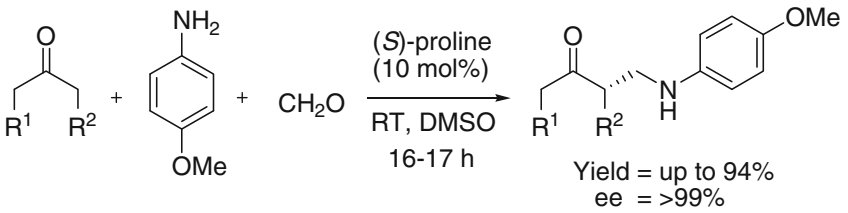

Scheme 2. Proline catalysed enantioselective Mannich reaction.

reactions. Herein, we present a representative example of proline catalysed highly enantioselective Mannich reaction of ketones (scheme 2). ${ }^{8}$

Similarly, proline and its derivatives catalyses; multicomponent synthesis of 3-amino alkylated indoles by Mannich-type reaction, ${ }^{9 \mathrm{a}}$ Mannich reaction of acetaldehyde, ${ }^{9 \mathrm{~b}}$ preparation of azole Mannich adducts, ${ }^{9 \mathrm{c}}$ three component domino reactions, ${ }^{9 \mathrm{~d}}$ enantioselective addition of ketones to chalkogenazines, ${ }^{9 \mathrm{e}}$ synthesis of [1,4]thiazines, ${ }^{9 f}$ asymmetric Mannich reaction of cyclic ketones, ${ }^{9 \mathrm{~g}}$ etc. In addition to this, various organocatalysed Mannich reactions have also been reported. ${ }^{10 \mathrm{a}-\mathrm{g}}$
Through quantum mechanical calculations, $\mathrm{Fu}$ et al. explained the origin of stereoselectivity in amino acid catalysed direct syn and anti selective Mannich reactions. ${ }^{11}$ Excellent reviews are available which provides significant insight into the proline/organocatalysed asymmetric Mannich-type reaction. ${ }^{12 \mathrm{a}-\mathrm{e}}$

\section{Applications of Mannich reaction in bioactive molecule synthesis}

The Mannich reaction and its variants are often employed to access diverse molecules, whose applications are ranging from bioactive skeletons to material science. A representative list of the bioactive/therapeutic molecules obtained by Mannich reaction and the role of Mannich reaction in total synthesis are presented in chart 1 . The aminocarbonyl Mannich products are useful in the construction of $\beta$-peptides and $\beta$-lactams, which are present in several bioactive molecules such as taxol (antitumour agent),

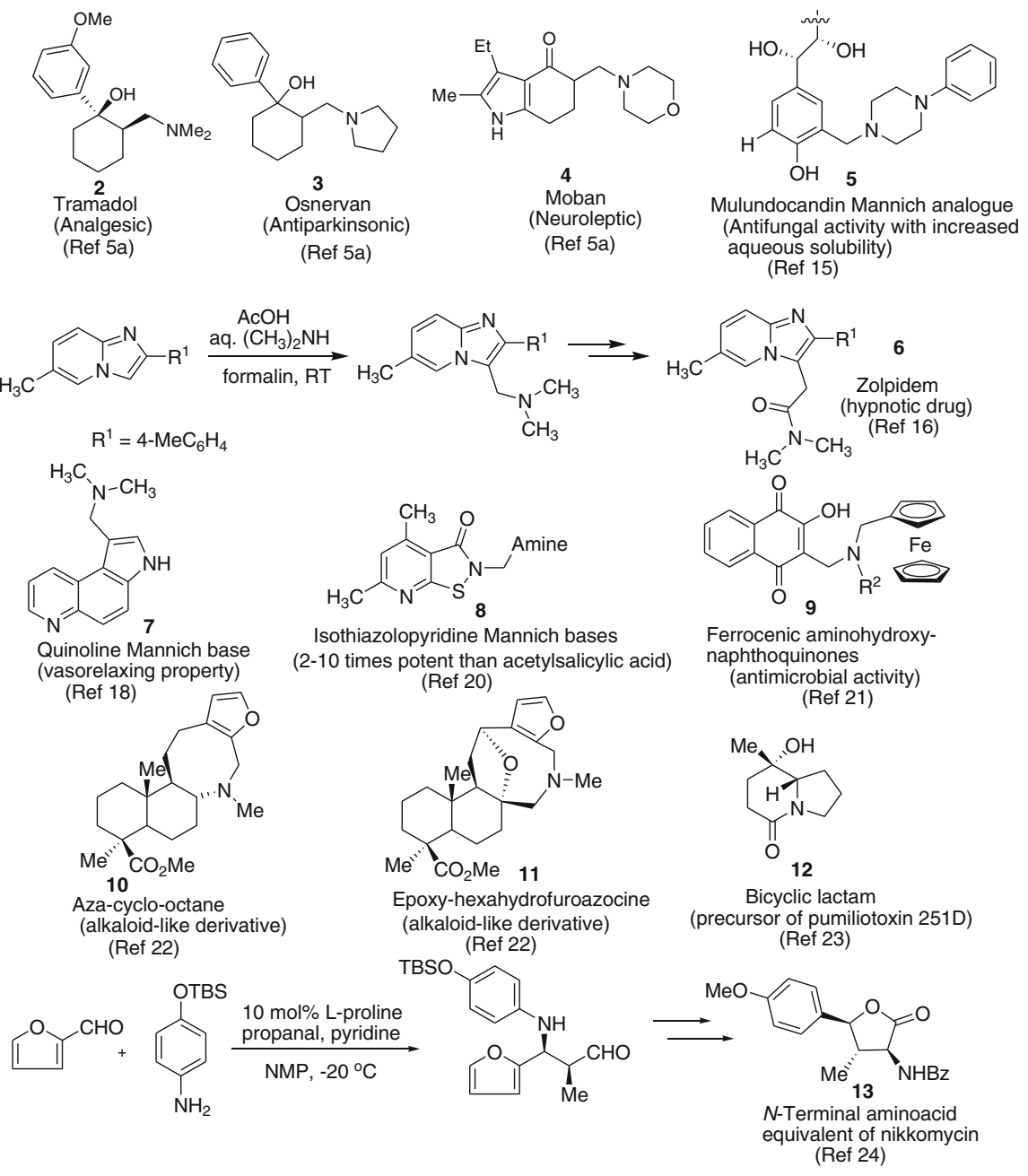

Chart 1. Bioactive Mannich derivatives. 


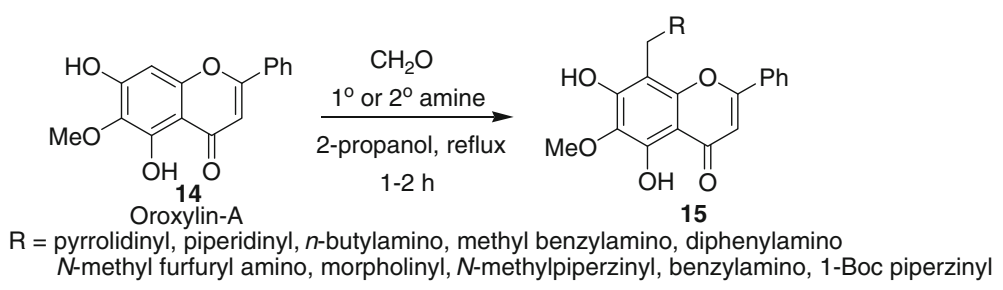

Scheme 3. Mannich reaction of oroxylin-A.

bestatine (immunological response modifier) and SCH48461 (anti-cholesterol agent). ${ }^{13 \mathrm{a}-\mathrm{d}}$ Tramadol 2, osnervan $\mathbf{3}$ and moban $\mathbf{4}$ are bioactive $\beta$-aminocarbonyl derivatives with analgesic, antiparkinson and neuroleptic properties (chart 1). ${ }^{5 \mathrm{a}}$ It is believed that the solubility of the Mannich derivatives increases in water due to protonation of basic amine nitrogen atom. ${ }^{14}$ Mulundocandin, a class of lipopeptides, showed excellent in vitro activity against Candida species. However, poor solubility restricts its widespread application. Lal et al. carried out a semi-synthetic modification of mulundocandin by Mannich reaction. ${ }^{15}$ The Mannich derivatives of mulundocandin $\mathbf{5}$ exhibited significant improvement in solubility, while retaining the activity (chart 1). Mannich reaction was useful for the preparation of zolpidem 6, a hypnotic drug used for the treatment of insomnia (chart 1). ${ }^{16}$ The Mannich bases are obtained by the condensation reaction of $\mathrm{C}-\mathrm{H}$ acidic substrates (ketones, phenols, etc.,), amine (cyclic or acyclic) and aldehyde. The Mannich bases are an important class of molecules with significant biological activity. The cationic surfactant molecules obtained from Mannich bases possess excellent fungicidal property along with good biocidal property against Gram-positive and Gram-negative bacteria. ${ }^{17}$ The quinoline derived Mannich base $\mathbf{7}$ possess vasorelaxing properties (chart 1). ${ }^{18}$ Such molecules are useful in the treatment of hypertension. 1,2,4-Triazole derived Mannich bases exhibited anticancer activity. ${ }^{19}$ The isothiazolopyridine derived Mannich bases 8 were found to be 2 to 10 times more potent than the reference drug acetylsalicylic acid (chart 1). ${ }^{20}$ The Mannich reaction is useful for the synthesis of ferrocenyl derived aminohydroxynaphthoquinones 9 (chart 1). ${ }^{21}$ These products exhibited good activity against Toxoplasma gondii and atovaquone resistant strain of $T$. gondii.

Mannich reaction also plays a significant role in bioactive skeleton target synthesis. Chernov et al. reported the synthesis of alkaloid-like molecules $\mathbf{1 0}$ and $\mathbf{1 1}$ from lambertianic acid via Mannich-type intramolecular ring closure reaction (chart 1). ${ }^{22}$ Martin et al. employed vinylogous Mannich reaction to synthesize bicyclic lactam 12, a key intermediate used in the total synthesis of alkaloid pumiliotoxin 251D (chart 1). ${ }^{23}$ Proline catalysed asymmetric Mannich reaction played a vital role in the synthesis of $N$-terminal amino acid equivalent moiety $\mathbf{1 3}$ of peptide antibiotic, nikkomycin (chart 1). ${ }^{24}$ Babu et al. synthesized biologically significant 8-aminoalkylated derivatives of oroxylin-A 15, by Mannich reaction. ${ }^{25}$ The $\alpha$-glucosidase inhibitory activity of the aminoalkyl derivatives was found to be superior to that of their parent molecule oroxylin-A 14 (scheme 3).

\subsection{Synthesis of antimalarial molecules}

Malaria is one of the most widespread infectious diseases in the world. Though effective antimalarial drug like chloroquine exists, drug resistance has become a great challenge. The development of new inexpensive antimalarial drugs is vital in developing countries to counter multi-drug resistant Plasmodium falciparum. ${ }^{26}$ The discovery of new molecular skeletons is always in need to circumvent the drug resistance and to provide good antimalarial activity. In 1997, Kotecka et al. reported the synthesis of chloroquine analogues, a quinoline based di-Mannich bases (16
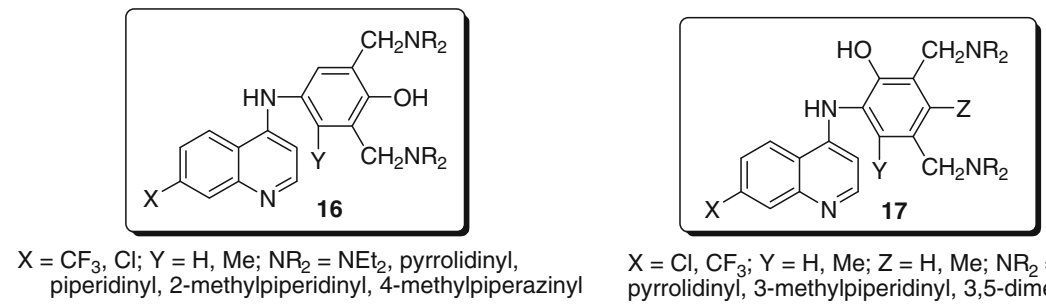

$\mathrm{X}=\mathrm{Cl}, \mathrm{CF}_{3} ; \mathrm{Y}=\mathrm{H}, \mathrm{Me} ; \mathrm{Z}=\mathrm{H}, \mathrm{Me} ; \mathrm{NR}_{2}=$ piperidinyl, pyrrolidinyl, 3-methylpiperidinyl, 3,5-dimethylpiperidinyl

Figure 1. Quinoline di-Mannich bases. 


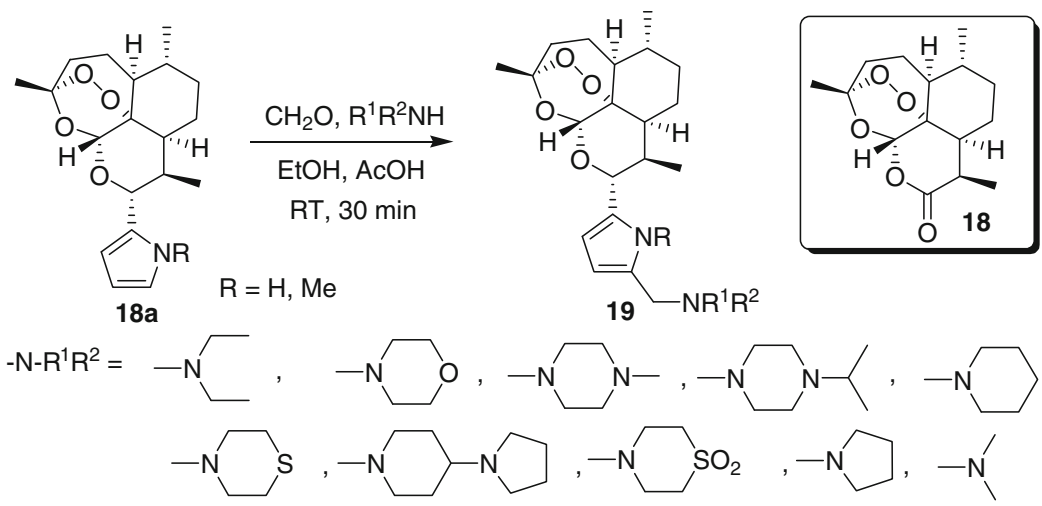

Scheme 4. Mannich reaction of artemisinin C-10 analogues.

and 17), and screened their activity against multi-drug resistant strains of Plasmodium falciparum (figure 1). ${ }^{26}$ The ex vivo antimalarial activity of the Mannich bases tested in serum were found to be greater than those of amodiaquine, chloroquine or pyronaridine.

The widespread application of artemisinin 18, an efficient antimalarial drug utilized in malaria chemotherapy, is limited due to its poor solubility in both water and oil. Moreover, artemisinin and its semi-synthetic analogues dihydroartemisinin, artemether, arteether, sodium artesunate are easily removed from the blood stream and hence lead to the resurgence of the parasite. ${ }^{27}$ It is postulated that the amine functionality embedded in artemisinin may enhance the drug activity by accumulating in parasitic acidic food vacuole. Pacorel et al. reported the synthesis of artemisinin Mannich derivatives 19, from C-10- $\alpha$-pyrroleartemisinin derivative 18a (scheme 4). ${ }^{27}$ The presence of Mannich side chain increases its solubility and hence bioavailability of the drug when compared to the non-basic derivatives. The morpholine and $N$-methylpiperazine derived semi-synthetic analogues were three times more potent than the natural product artemisinin against both chloroquine sensitive and resistant strains.

Malarial infections can be controlled by inhibiting cysteine proteases, a sulfur-containing vital enzyme used for the haemoglobin hydrolysis by the parasite. ${ }^{28}$ The phenolic Mannich bases possess good biological activity partially due to the liberation of $\alpha, \beta$-unsaturated ketones by deamination. The $\alpha, \beta-$ unsaturated ketones have good affinity toward thiols and hence they may selectively bind and inhibit the cysteine proteases. Chipeleme et al. synthesized phenolic Mannich bases $\mathbf{2 0}$ by treating equimolar quantities of 2,4-dihydroxybenzaldehyde, formaldehyde and secondary amine in ethanol solvent (scheme 5). ${ }^{28}$ The phenolic Mannich bases subsequently converted to the corresponding (thio)semicarbazone $\mathbf{2 1}$ and aminoquinoline semicarbazone derivatives. The 4aminoquinoline semicarbazones effectively inhibit falcipain-2, the cysteine protease present in Plasmodium falciparum; while bisquinoline semicarbazone 22 exhibited good antimalarial activity with an $\mathrm{IC}_{50}$ of $0.07 \mu \mathrm{M}$ against chloroquine resistant strain of Plasmodium falciparum.

The factors that determine the transformation of a bioactive skeleton to a drug are adsorption, distribution, metabolism and excretion (ADME) properties. ${ }^{29}$ Hence, early prediction of ADME properties could lead to better identification of therapeutic molecules. Based on this, Guantai et al. reported a new antimalarial hybrid compound by replacing the triazole tether

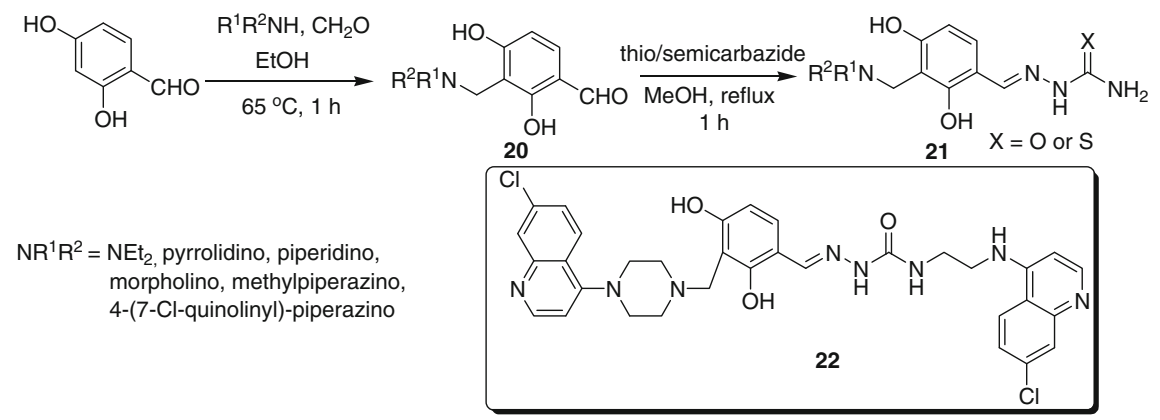

Scheme 5. Synthesis of quinoline semicarbazone. 
group of an existing molecule with piperazinyl moiety. ${ }^{29}$ The target molecules $\mathbf{2 5}$ and $\mathbf{2 6}$ were obtained by the Mannich reaction of piperazinyl derivative $\mathbf{2 3}$ with formaldehyde and chalcone $\mathbf{2 4}$ in ethanol solvent (scheme 6). The compounds $\mathbf{2 5}$ and $\mathbf{2 6}$ were found to be the most active analogues against Plasmodium falciparum. The piperazinyl tethered derivatives possess good antimalarial properties along with improved solubility.

Amodiaquine 27, a 4-aminoquinoline antimalarial drug is effective for treating both chloroquine sensitive and resistant strains of Plasmodium falciparum. However, enzymatic in vivo oxidation of amodiaquine by cytochrome P-450 could form amodiaquine quinoneimine (AQQI) 28; a reactive metabolite that could lead to side effects such as agranulocytosis and liver damage (scheme 7). ${ }^{30}$
Hence, prolonged use of amodiaquine is restricted. It was hypothesized that the interchange of amine and hydroxyl functionality would lead to the formation of new amodiaquine Mannich analogue, isoquine 29a, that resist oxidation by cytochrome P-450 enzyme. In 2003, O'Neill et al. reported the synthesis of isoquine analogues by coupling chloroquinoline with phenolic Mannich bases 30 (scheme 8). ${ }^{30}$ The isoquine products 29b thus obtained exhibited good antimalarial activity; and hence it offers an effective and safe alternative to amodiaquine.

Amodiaquine $N$-Mannich base derivatives exhibited good stability, antimalarial activity against multi-drug resistant Plasmodium falciparum. ${ }^{31}$ Later, Saha et al. prepared isoquine derivatives 29c and examined their efficacy against chloroquine sensitive strains of Plasmodium falciparum (figure 2). ${ }^{32}$ However, the<smiles>[R]Oc1ccc(C(=O)/C=C/c2ccc(O)c(OC)c2)c(OC)c1</smiles><smiles>[R]c1cc(/C=C/C(=O)c2ccc(OC)cc2OC)cc(CN2CCN(c3ccnc4cc([18OH])ccc34)CC2)c1O</smiles>

Scheme 6. Synthesis of antimalarial hybrid compounds by Mannich reaction.

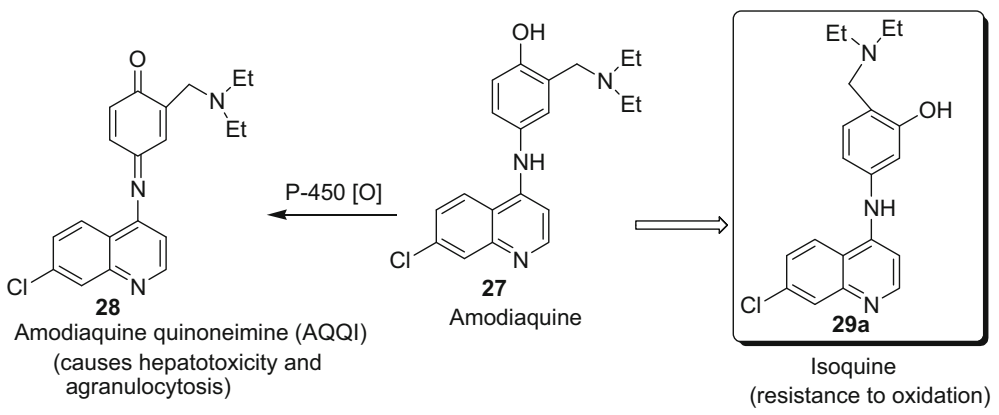

Scheme 7. Oxidative disintegration of amodiaquine.

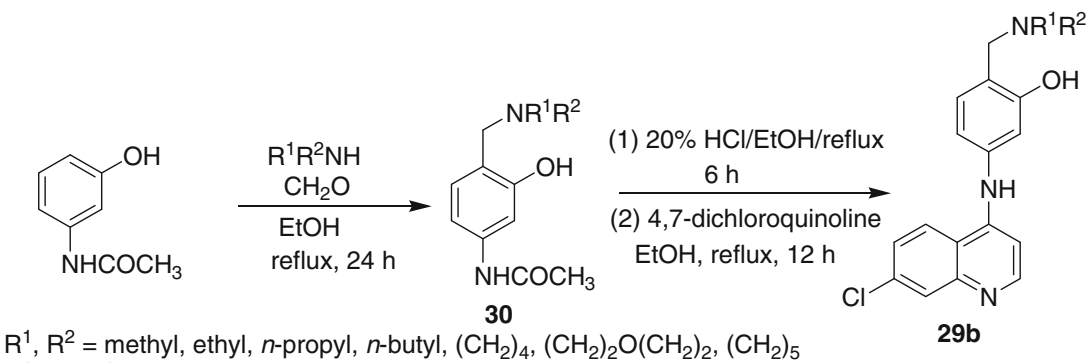
$\mathrm{R}^{1}=\mathrm{H}, \mathrm{R}^{2}=$ Et or $i$-propyl or $t$-butyl

Scheme 8. Synthesis of isoquine analogues by Mannich reaction. 
synthesized analogues were found to be inferior to the antimalarial drug chloroquine. The nature of Mannich substituent plays a significant role in determining the activity of isoquine derivatives.

The 4-aminoquinoline derived Mannich bases 31 and $\mathbf{3 2}$ showed good antimalarial activity (figure 3). ${ }^{33 \mathrm{a}}$ However, the Mannich analogues displayed higher cytotoxicity to the mammalian cells, especially to highly drug-resistant glioblastoma cell line. Hence, these Mannich bases could be used as antiproliferative agents rather than antimalarial drugs.

Akin to amodiaquine 27, tebuquine 33, a 4aminoquinoline antimalarial drug undergoes oxidative

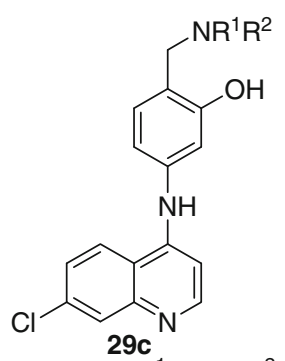

$\mathrm{R}^{1}, \mathrm{R}^{2}=-\mathrm{CH}_{2} \mathrm{CH}_{2} \mathrm{OH}, i$-propyl; $\mathrm{R}^{1}=\mathrm{Ph}, \mathrm{R}^{2}=\mathrm{H} ; \mathrm{R}^{1}=\mathrm{H}, \mathrm{R}^{2}=\mathrm{CSNH}_{2}$

Figure 2. Isoquine derivatives.

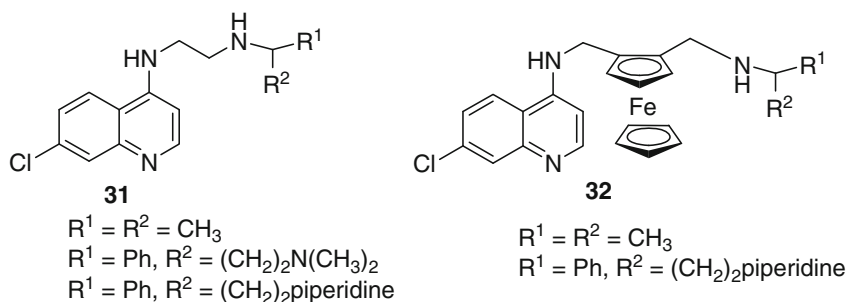

Figure 3. 4-Aminoquinoline Mannich bases. disintegration to form toxic tebuquine quinoneimine. Miroshnikova et al. synthsized isotebuquine analogues 34a-e by Mannich reaction and the products exhibited good antimalarial activity (scheme 9). ${ }^{33 \mathrm{~b}}$

Interestingly, mono-Mannich base derivatives were found to be more active than the di-Mannich base derivatives.

\subsection{Synthesis of antitumour molecules}

Highly drug-resistant tumour cells limit the success rate of the cancer chemotherapy. The use of doxorubicin, an anthracycline chemotherapeutic agent causes multidrug resistance in tumour cells. The anthracycline synthetic analogue 4,11-dihydroxynaphtho[2,3$f$ ]indole-5,10-dione Mannich base 35 showed significant activity against multi-drug resistant tumour cell lines (figure 4). ${ }^{34 a}$ The presence of aminoalkyl Mannich side chain is essential to formulate water soluble antitumour agent 36 (figure 4). ${ }^{34 \mathrm{~b}}$ The gatifloxacin Mannich derivative 37 showed excellent anticancer activity compared to the standard anticancer drug etoposide (figure 4). ${ }^{34 \mathrm{c}}$ Acetophenone Mannich derivatives $\mathbf{3 8}$ exhibited good activity against Jurkat cell lines (figure 4). ${ }^{34 \mathrm{~d}}$ The recent applications of Mannich reaction in construction of antitumour skeleton is presented here.

Antimitotic agents play a significant role in treating multi-drug resistant tumours. Both tryprostatin A and B obtained from natural source, act as antimitotic agents. Yamakawa et al. employed Mannich reaction as one of the synthetic pathway to prepare tryprostatin A and B. ${ }^{34 \mathrm{e}}$ Scheme 10 depicts the total synthesis of tryprostatin A 40a by coupling 2-prenylindole intermediate

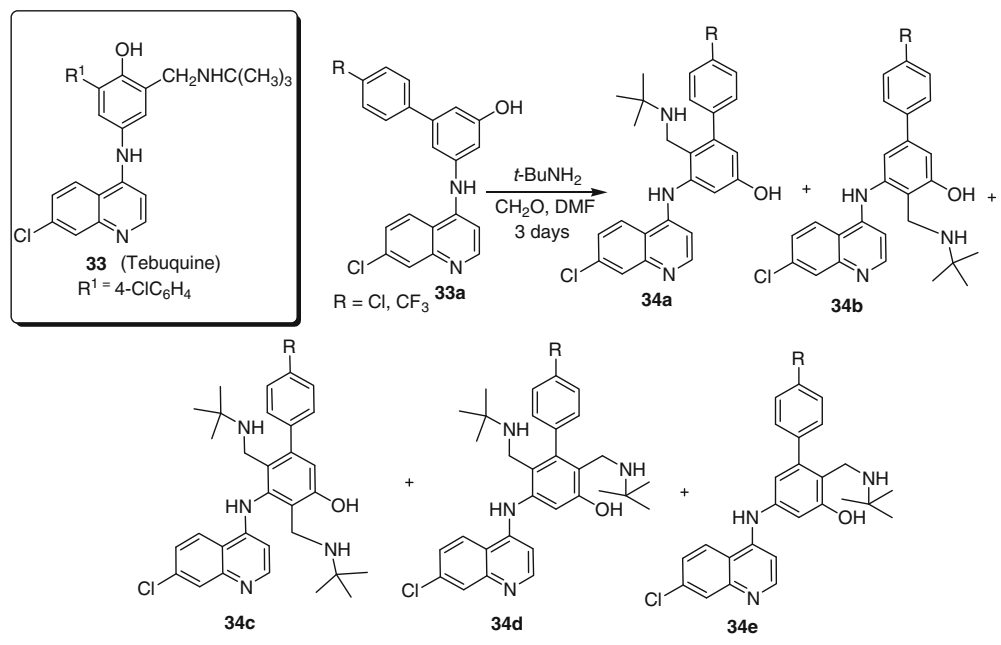

Scheme 9. Synthesis of isotebuquine analogues by Mannich reaction. 

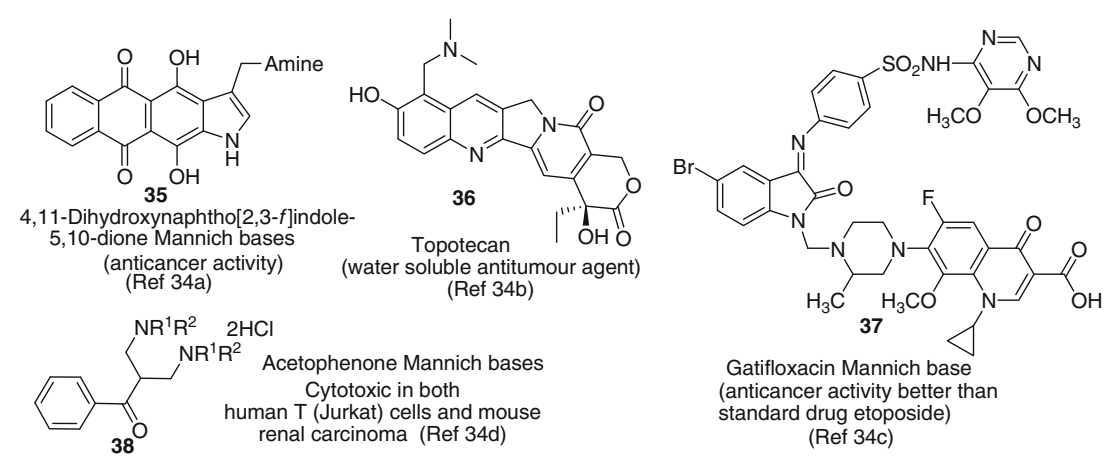

Figure 4. Antitumour Mannich derivatives.

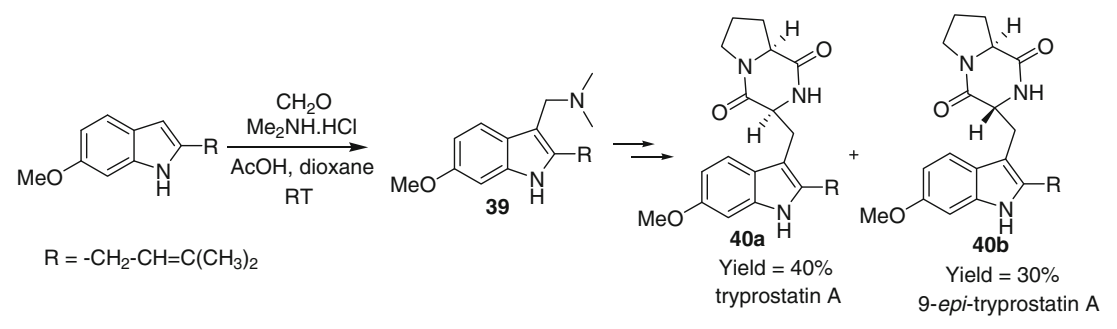

Scheme 10. Tryprostatin synthesis by Mannich reaction.

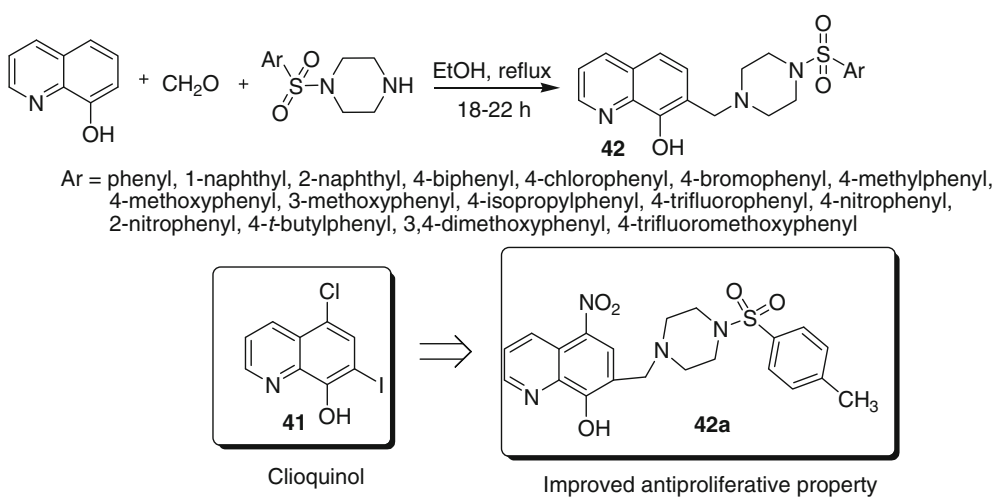

Scheme 11. Clioquinol Mannich derivatives-I.

39 with diketopiperazine core. However, the selectivity achieved in this reaction was poor.

Clioquinol 41, an 8-hydroxyquinoline derivative possesses antibiotic, anti-Alzheimer, and moderate antiproliferative properties. Shaw et al. studied the structureactivity relationship (SAR) of 8-hydroxyquinoline derived Mannich bases $\mathbf{4 2}$ as anticancer agents (scheme 11). ${ }^{35}$ The SAR studies revealed that the presence of 8-hydroxyquinoline core was essential for the activity. The Mannich derivative 42a was found to be active against both $\mathrm{HeLa}$ and BT483 cells with $\mathrm{GI}_{50}$ values of 0.7 and $1.9 \mu \mathrm{M}$, respectively.

The reactive oxygen species (ROS) such as hydrogen peroxide, singlet oxygen, hydroxyl radical, etc., plays a major role in determining cell proliferation and apoptosis (cell death). The low level ROS induces cell proliferation, while the medium level arrest the cell growth; and the excess ROS causes apoptosis. ${ }^{36}$ Chen et al. reported the synthesis of clioquinol Mannich derivatives $\mathbf{4 3}$ and established that they trigger production of ROS and exhibit cytotoxicity (scheme 12). ${ }^{36}$ The derivatives are 26 times more potent than the parent analogue, against HeLa cell line. The studies confirm the fact that the presence of Mannich side chain improves the activity of an existing bioactive molecule.

The semi-synthetic lactone analogue 44 obtained from the natural product $6 \alpha, 7 \beta$-dihydroxyvouacapan$17 \beta$-oic acid, showed better anticancer activity than 
the corresponding parent carboxylic acid molecule. It was proposed that the aminoalkyl Mannich derivatives could further improve the efficacy of bioactive molecule 44. Euzébio et al. synthesized $6 \alpha$ hydroxyvouacapan-7 $\beta, 17 \beta$-lactone Mannich derivatives 45 and the products exhibited good antiproliferative activity against NCI-ADR/RES, NCI-H460 and K562 cancer cell lines (scheme 13). ${ }^{37}$ The Mannich bases 45 displayed similar potency as that of reference drug doxorubicin. Theoretical studies on Mannich bases indicated that the aminoalkyl Mannich side chain plays a vital role in determining antiproliferative activity.

Longshaw et al. developed Mannich reaction assisted synthesis of sulfur-free transition state analogue inhibitors of human MTAP (an anticancer target). ${ }^{38}$

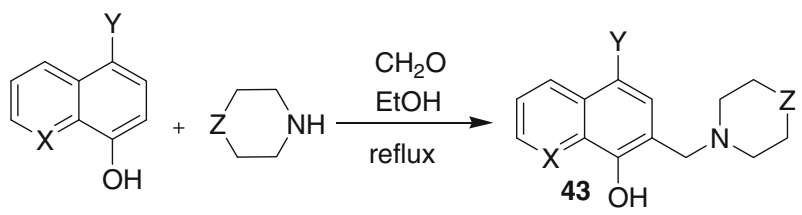

$\mathrm{X}=\mathrm{N}, \mathrm{CH} ; \mathrm{Y}=\mathrm{H}, \mathrm{NO}_{2} ; \mathrm{Z}=\mathrm{CH}_{2}, \mathrm{NSO}_{2} \mathrm{Ph}, \mathrm{NSO}_{2} \mathrm{C}_{6} \mathrm{H}_{4}\left(4-\mathrm{CH}_{3}\right)$

Scheme 12. Clioquinol Mannich derivatives-II.

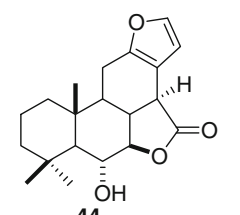
$\mathrm{R}^{1,} \mathrm{R}^{2}=-\mathrm{CH}_{2} \mathrm{CH}_{3},-\mathrm{CH}_{2} \mathrm{CH}_{2} \mathrm{CH}_{3},-\mathrm{CH}_{2} \mathrm{CH}\left(\mathrm{CH}_{3}\right)_{2},-\left(\mathrm{CH}_{2}\right)_{4^{-}},-\left(\mathrm{CH}_{2}\right)_{5^{-}}$, -

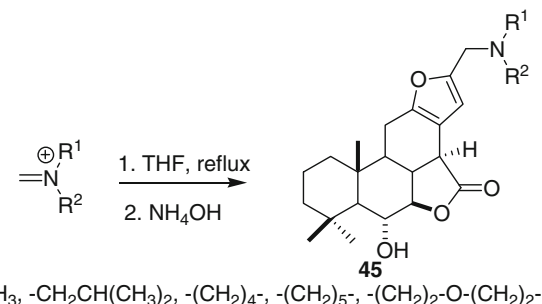

Scheme 13. Hydroxyvouacapan-7 $\beta, 17 \beta$-lactone Mannich derivative synthesis.
Benzothiazoles are an important class of molecules with powerful antitumour activity. ${ }^{39 a, b}$ The benzothiazole derivative 46, is an orally active, potent antitumour agent, used for treating solid tumours (scheme 14).

Kumbhare et al. reported zinc chloride catalyzed Mannich reaction of 2-arylimidazo[2,1b] benzothiazoles 47 (scheme 14). ${ }^{40 a}$ The Mannich base product 48a showed significant anticancer activity against MCF-7, HeLa and HepG2 cell lines and hence, it could be an effective lead for benzothiazole based anticancer drug molecules.

Aminophosphonates, an interesting class of organic compounds with antibacterial and antiproliferative/ antitumour properties. ${ }^{40 \mathrm{~b}-\mathrm{d}}$ Jin et al. employed Mannichtype reaction to synthesize $\alpha$-aminophosphonates by reacting substituted benzothiazole 49 , dialkyl phosphite and substituted benzaldehyde in ionic liquids (scheme 15). ${ }^{40 \mathrm{e}}$ The Mannich reaction provides a clean and atom economic method to access $\alpha$ aminophosphonates 50. The ionic liquid $\left[\mathrm{bmim}^{2}\left[\mathrm{PF}_{6}\right]\right.$, accelerated the Mannich addition reaction to severalfolds and the products were obtained in excellent yield. The benzothiazole substituted $\alpha$-aminophosphonate 50a was active against PC 3 cell lines.

The chalcone Mannich bases exhibited good cytotoxicity against leukemia and several other human tumour cell lines. Reddy et al. stated that 'presence of a Mannich base group in chalcones and other compound types may increase biological potency due to the greater number of molecular sites for electrophilic attack by cellular constituents'. ${ }^{41}$ The chalcone derivatives $\mathbf{5 2}$ were synthesized by condensing substituted acetophenone Mannich bases $\mathbf{5 1}$ with heterocyclic/aromatic aldehydes (scheme 16). The chalcone derivatives $\mathbf{5 3}$ and $\mathbf{5 4}$ showed good activity against MCF-7 breast cancer cell line.

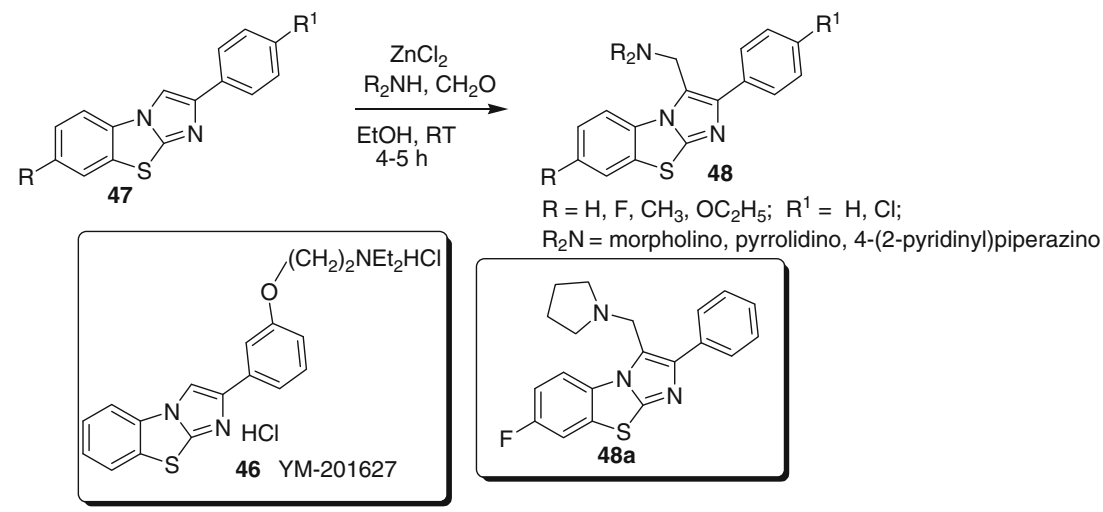

Scheme 14. Synthesis of benzothiazole Mannich bases. 


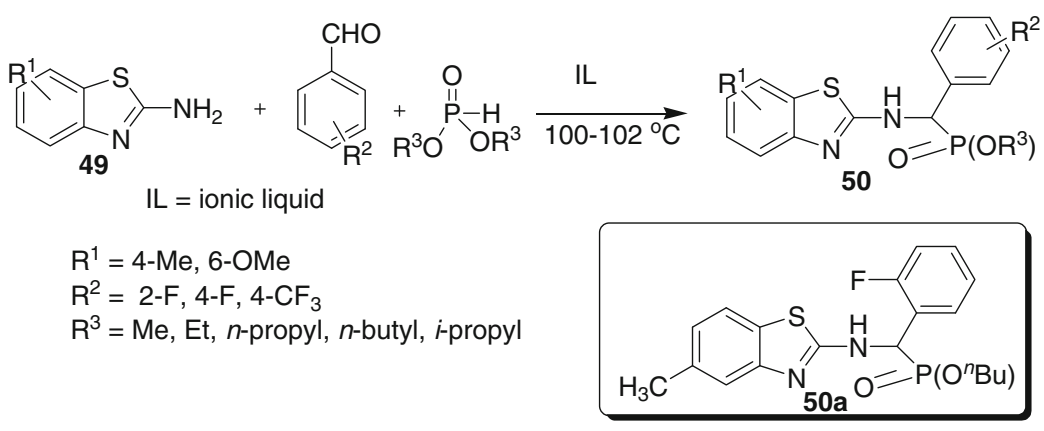

Scheme 15. $\alpha$-Aminophosphonate Mannich bases.

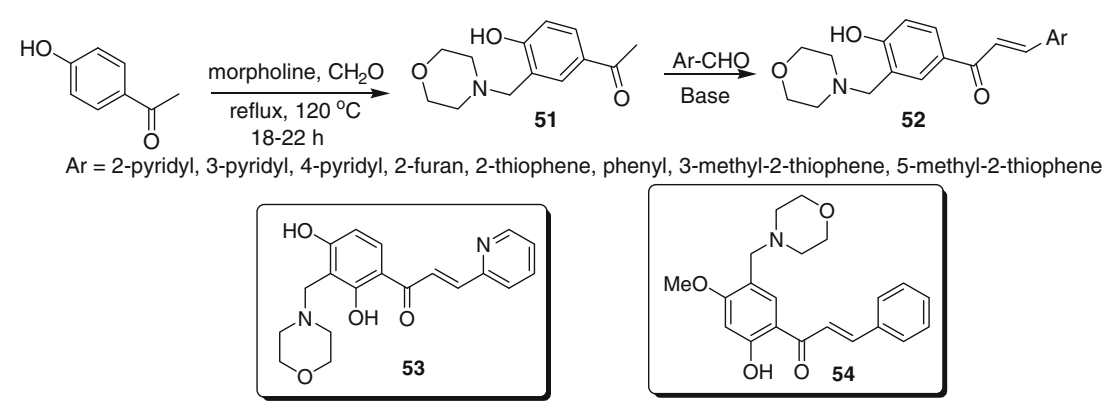

Scheme 16. Heterocyclic chalcone Mannich bases.

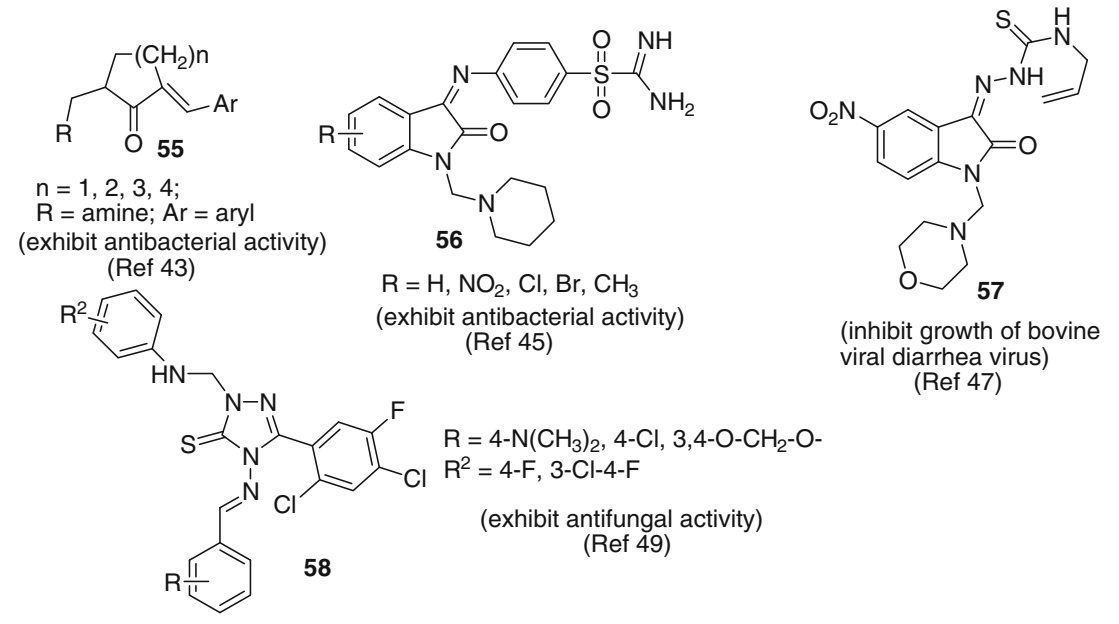

Figure 5. Representative list of antimicrobial agents.

\subsection{Synthesis of antimicrobial agents}

The development of new antimicrobial agents is needed to counter the increasing number of multi-drug resistant (MDR) strains. ${ }^{42 a}$ The multiple mechanisms operating in the bacteria makes them highly resistant to widely used antibacterial drugs and hence newer generation antibiotics are in need to evade the drug resistance mechanism. The Mannich reaction has been useful in the preparation of various antimicrobial mole- cules. ${ }^{42 \mathrm{~b}-\mathrm{f}}$ Lóránd et al. studied the antibacterial properties of unsaturated Mannich ketones 55 (figure 5). ${ }^{43}$ The presence of Mannich side chain increases the water solubility of the unsaturated Mannich ketones. Hence, the Mannich derivatives are easily transported to the site of action and they were found to be more potent than the parent molecule. Moreover, the antibacterial Mannich products displayed much less cytotoxicity, which is a vital requirement for a molecule to be developed as drug. Later, Lóránd et al. also reported that 
the reduction of cyclic Mannich ketone to the corresponding alcohol led to a significant loss in antibacterial activity. ${ }^{44}$

The Mannich base derivative of isatin-4-amino- $N$ carbamimidoyl benzenesulphonamide Schiff's base $\mathbf{5 6}$ was found to be more active than the reference drug sulphaguanidine (figure 5). ${ }^{45}$ The studies on 2-[(2,6dichlorophenyl)amino]phenylacetic acid isatin derivatives revealed that the presence of bulky phenyl acetic acid moiety could reduce the antimicrobial potency of isatin derivatives. ${ }^{46}$ The Mannich derivative of indole2,3-dione derivative $\mathbf{5 7}$ inhibit the growth of bovine viral diarrhea virus in MDBK CODA cells (figure 5). ${ }^{47}$ Joshi et al. accomplished the synthesis of non-toxic aminoalkyl substituted isonicotinyl hydrazide by Mannich reaction. ${ }^{48}$ The Mannich products were found to be more active against several Gram-positive and Gram-negative bacteria. Karthikeyan et al. reported the synthesis and biological activity of 2,4-dichloro-5fluorophenyl substituted Mannich base derivatives 58 (figure 5). ${ }^{49}$ The Mannich base derivatives showed good antibacterial and antifungal properties.

Recently, Plech et al. reported the synthesis of triazolinothione Mannich bases 60, by reacting 1,2,4triazolino-3-thione 59, pyrrolidine and formaldehyde in ethanol solvent (scheme 17). ${ }^{50}$ The studies revealed that the presence of Mannich side chain in $\mathbf{6 0}$ imparts several-fold increase in antibacterial activity.

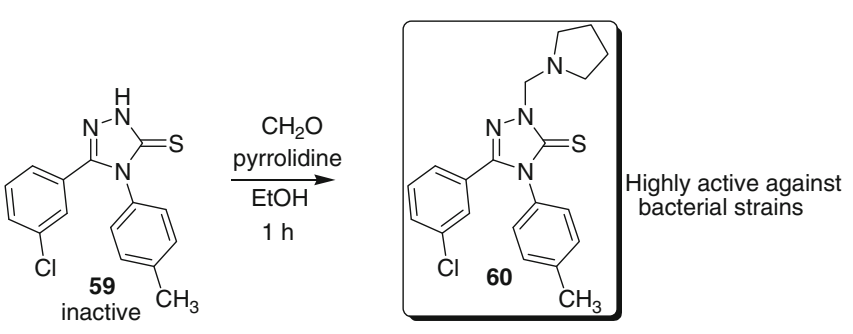

Scheme 17. Triazolino-3-thione Mannich derivatives.
Mazzei et al. reported the synthesis and antiviral studies of Mannich bases $\mathbf{6 1}$ and the corresponding propyl ether derivative of Mannich bases 62 (scheme 18). ${ }^{51}$ It is interesting to note here that the Mannich derivative with free hydroxyl functionality $\mathbf{6 1}$ exhibits negligible antiviral activity against hepatitis $\mathrm{C}$ surrogate viruses. It is only the Mannich ether derivative 62 that exhibits good antiviral activity.

The pharmaceutically important bischromones can be synthesized using Mannich reaction. ${ }^{52}$ Bischromones with ester or carboxylic acid functionalities act as cure for hay fever, urticaria and viral infections. The reaction of bischromone-3,3'-dicarboxaldehyde 63, $N$-methylglycine and formaldehyde gave the corresponding di- $N$-(chromone-3-ylmethyl)- $N$-methylglycine 64 in moderated to good yields (scheme 19). The bischromones with $\alpha$-amino acid are pharmaceutically important molecules and can also be used as fluorescent marker.

Mannich reaction offers an effective method to synthesize $\beta$-amino carbonyl derivatives. The $\mathrm{CeCl}_{3}$ catalysed, microwave-assisted three-component Mannich reaction of ketones, aromatic aldehydes and amines under neat condition gave the corresponding $\beta$-aminocarbonyl product 65 in excellent yield (scheme 20). ${ }^{53}$ Most of the Mannich derivatives exhibited significant antibacterial activity as compared to that of standard drug, ceftriaxone.

In addition to the aforementioned Mannich derivatives, quinazoline thione Mannich bases 66, carboxamide derived Mannich bases 67 and acetophenone derived Mannich bases 68 also possess good antimicrobial activity (figure 6). ${ }^{54-56}$ The Mannich derivatives 68 exhibit 2 to 16 times higher antifungal activity than the reference molecule amphotericin B.

2.3a Synthesis of antitubercular molecules: Due to multi-drug resistance, Gram-negative bacteria and Mycobacterium are difficult to treat with currently available antibiotics. Partial/insufficient treatment is

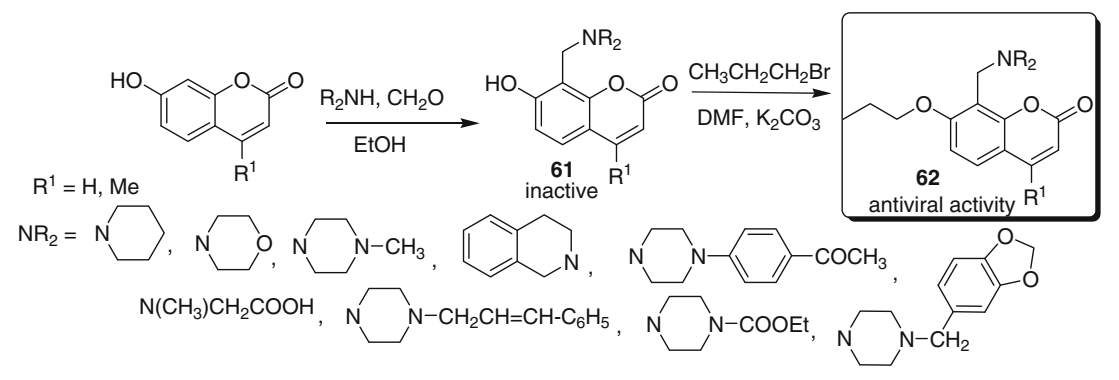

Scheme 18. Antiviral Mannich derivatives. 


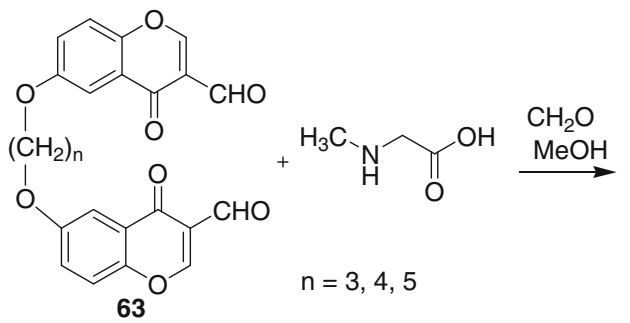<smiles></smiles>

Scheme 19. Deformylative Mannich-type reaction of bischromones.

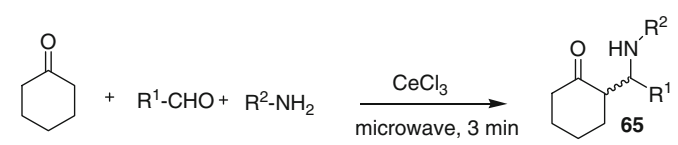

$\mathrm{R}^{1}$ - $\mathrm{CHO}=$ benzaldehyde, 4-fluorobenzaldehyde, 2-chlorobenzaldehyde, 2-fluoro-5-methoxybenzaldehyde, benzofuran-2aldehyde, pyridine-4-carboxaldehyde, 2-allyloxybenzaldehyde, 2-hydroxy-3-methylbenzaldehyde, 4-

ethylbenzaldehyde; $\mathrm{R}^{2}$ - $\mathrm{NH}_{2}=t$-butylaniline, 2,4-difluoroaniline, 4-cyanoaniline, 3,4-difluoroaniline, 3-fluoroaniline,

3,4,5-trifluoroaniline, 3-methoxyaniline, 2-methyl-5-aminoindole, naphthylamine

Scheme 20. Antibacterial Mannich- $\beta$-amino ketone derivatives.<smiles>NCCn1c(=S)n2c3ccccc3nc2c2ccccc21</smiles>

66

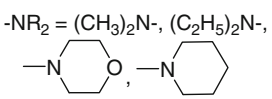
(Ref 54)

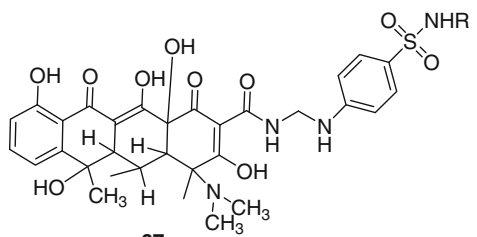

67

$\mathrm{R}=$ sulphadiazene, sulphamethoxazol, sulphanilamide, sulphaguanidine sulphadoxine, sulphacetamide

(Ref 55)

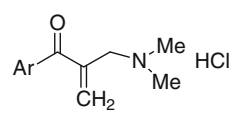

68

$\mathrm{Ar}=\mathrm{C}_{6} \mathrm{H}_{5}, 4-\mathrm{MeC}_{6} \mathrm{H}_{4}, 4-\mathrm{MeOC}_{6} \mathrm{H}_{4}$ 4- $-\mathrm{ClC}_{6} \mathrm{H}_{4}, 4-\mathrm{FC}_{6} \mathrm{H}_{4}, 4-\mathrm{BrC}_{6} \mathrm{H}_{4}$

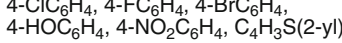

(Ref 56)

Figure 6. Antimicrobial derivatives.
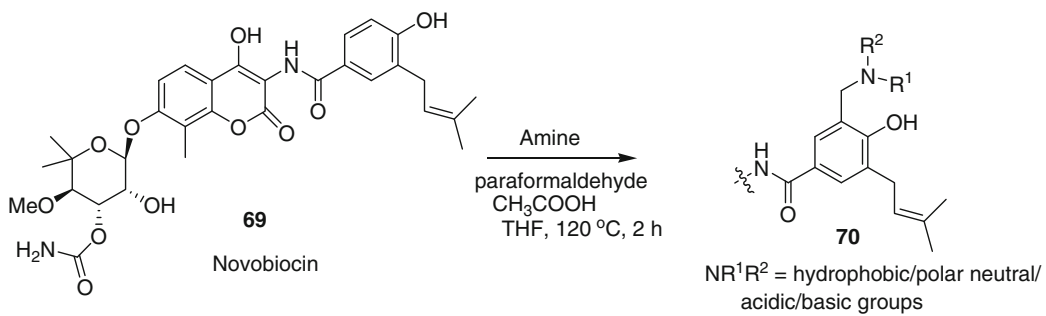

Scheme 21. Novobiocin Mannich derivatives.

one of the prime reasons for the resurgence of multidrug resistant tuberculosis (MDR-TB). The presence of MDR-TB has led to the development of new effective and less toxic drug candidates. The isatin Mannich base derivative exhibits several interesting biological activity such as antiviral, antifungal, antibacterial including antitubercular activity. ${ }^{57 \text { a }}$ The structural modification of the bioactive molecule could improve its desirable properties. The reaction of novobiocin 69, amine and paraformaldehyde in the presence of acid catalyst yielded the corresponding Mannich derivative 70 (scheme 21). ${ }^{57 b}$ The Mannich products exhi- bited better activity than novobiocin against the $M$. tuberculosis.

Parthiban et al. reported the synthesis of 2,4-diaryl-3azabicyco[3.3.1]nonan-9-one $O$-methyloximes 72a and the corresponding $N$-methyl analogs through modified Mannich reaction (scheme 22). ${ }^{58}$

The Mannich product 72b displayed promising activity against Mycobacterium tuberculosis. The Mannich reaction of substituted triazole, formaldehyde and cyclic amines in ethanol-dioxane solvent mixture gave the corresponding triazole Mannich derivative $\mathbf{7 3}$ (scheme 23). ${ }^{59}$ The mannich products thus obtained 73a 

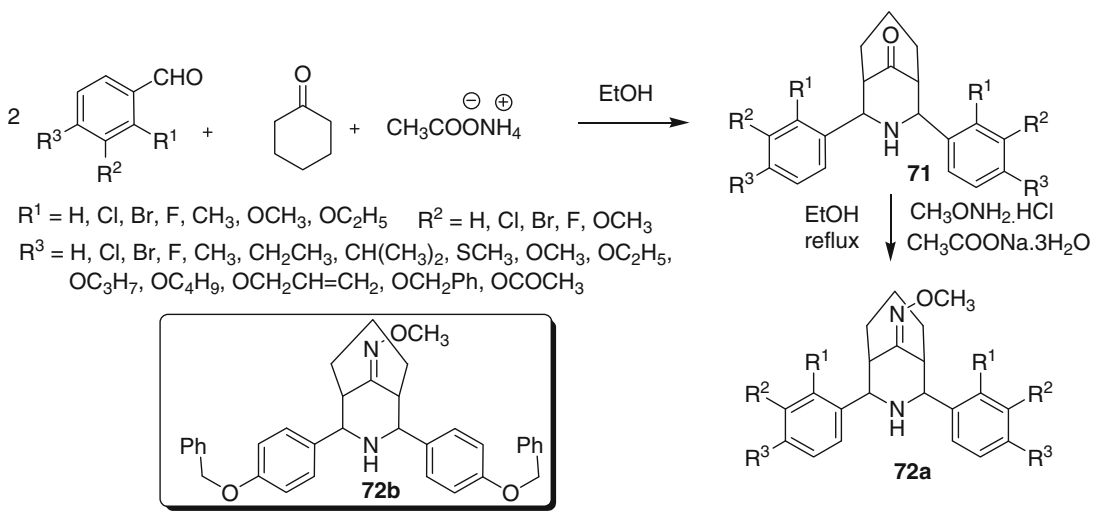

Scheme 22. Antitubercular Mannich derivatives-I.
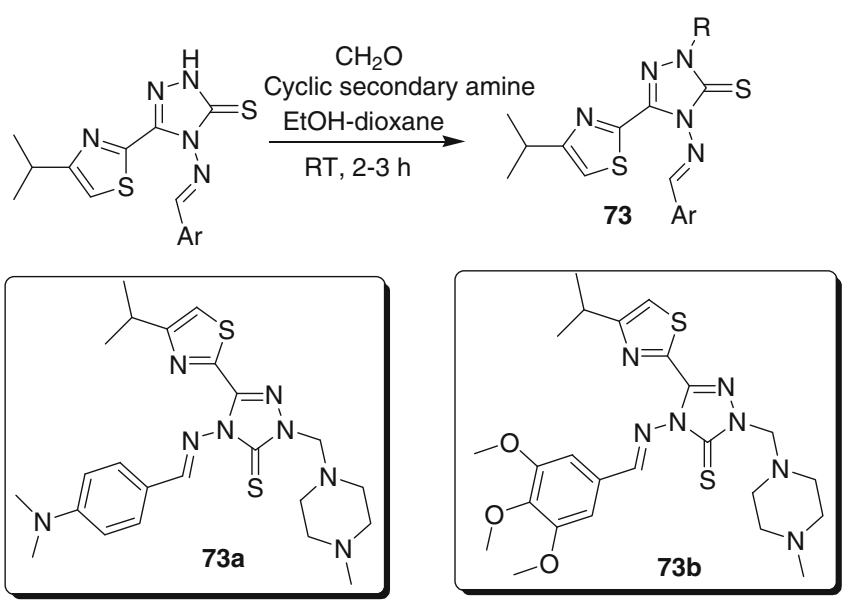

Scheme 23. Antitubercular Mannich derivatives-II.

and $\mathbf{7 3 b}$ exhibited excellent antitubercular activity akin to first line drug, isoniazid.

\subsection{Synthesis of antiinflammatory molecules}

Antiinflammatory drugs are used to treat pain and inflammation. Ibuprofen is a well-known non-steroidal antiinflammatory drug. Prolonged use of ibuprofen leads to ulceration and nephrotoxicity. ${ }^{60 a}$ The carboxyl derivative of non-steroidal antiinflammatory drug exhibits improved antiinflammatory properties with minimal side effects. ${ }^{60 \mathrm{~b}}$ Sujith et al. reported the Mannich reaction of ibuprofen triazole derivatives $\mathbf{7 4}$ with formaldehyde and secondary amine (scheme 24$){ }^{60 \mathrm{c}}$

The ibuprofen Mannich derivative 75a showed excellent antiinflammatory activity than the parent molecule. Moreover, the product also exhibited good analgesic effect. The analgesic effect of compound 75 was higher than the reference drug, diclofenac. The condensation of heterocyclic aldehydes with acetophenone Mannich bases yielded the corresponding heterocyclic chalcone Mannich derivatives 76a-d (figure 7). ${ }^{61}$
The Mannich products 76a and 76c exhibited good inhibitory action against nitric oxide (NO) production while the products $\mathbf{7 6} \mathbf{b}$ and $\mathbf{7 6 d}$ displayed good inhibition of $\mathrm{O}_{2}^{-}$generation. Hence, these Mannich derivatives are potential lead molecules for antiinflammatory drugs. Fabio et al. employed metal triflate mediated asymmetric Mannich-type condensation reaction to synthesize orally bioavailable antihyperalgesic tetrahydroquinoline derivative 77 (figure 7). ${ }^{62}$

\subsection{Synthesis of anticonvulsant molecules}

Anticonvulsant molecules are used to treat epileptic seizures, bipolar disorder and neuropathic pain. The currently available antiepileptic drugs phenytoin, mephobarbital induce side effects such as sedation and hypnosis. ${ }^{63}$ There is ever-mounting need for new anticonvulsant agents to control all kinds of fits, with minimal or no side effects. Recently, Obniska et al. reported the synthesis and studies of Mannich bases derived from $[7,8-f]$ benzo-2-azaspiro[4.5]decane-1, 3-dione and [7,8- $f]$ benzo-1,3-diaza-spiro-decane-2,4dione 78 (scheme 25). ${ }^{64}$ The Mannich reaction of (di)azaspirodiones with substituted piperazine/ morpholine and formaldehyde gave the corresponding Mannich bases $\mathbf{7 9}$ and $\mathbf{8 0}$ in moderate to good yields. The Mannich products have better activity than the reference drug, phenytoin.

The preparation of substituted urea derivatives by Mannich reaction has been reported recently (scheme 26). ${ }^{65}$ The Mannich derivative 1-(4chlorobenzylidene)-3-(1-(morpholinomethyl)-2,3dioxoindolin-5-yl)urea $\mathbf{8 1}$ possess significant antiepileptic property with the absence of neurotoxicity.

Byrtus et al. synthesized Mannich derivatives of 5-cyclopropyl-5-phenyl-imidazolidine-2,4-dione. ${ }^{66}$ 


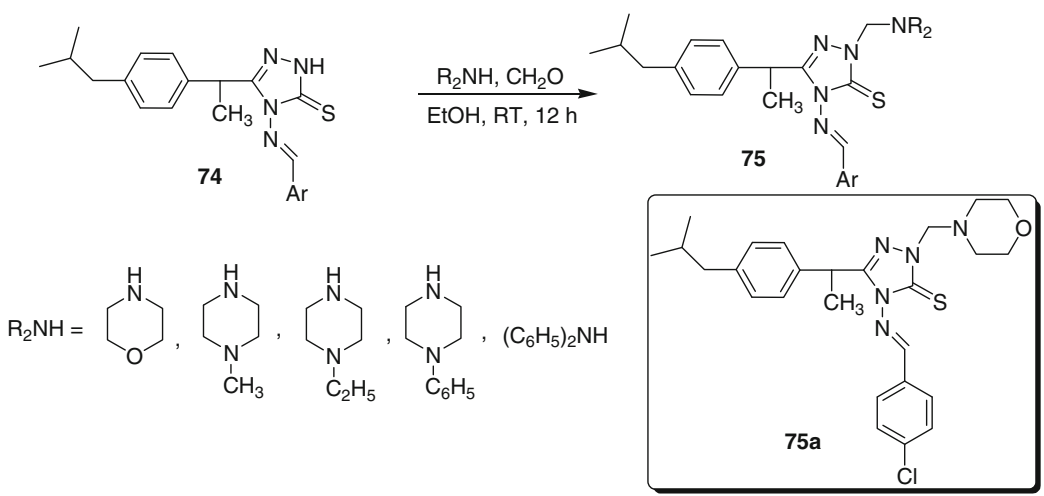

Scheme 24. Ibuprofen Mannich analogues.

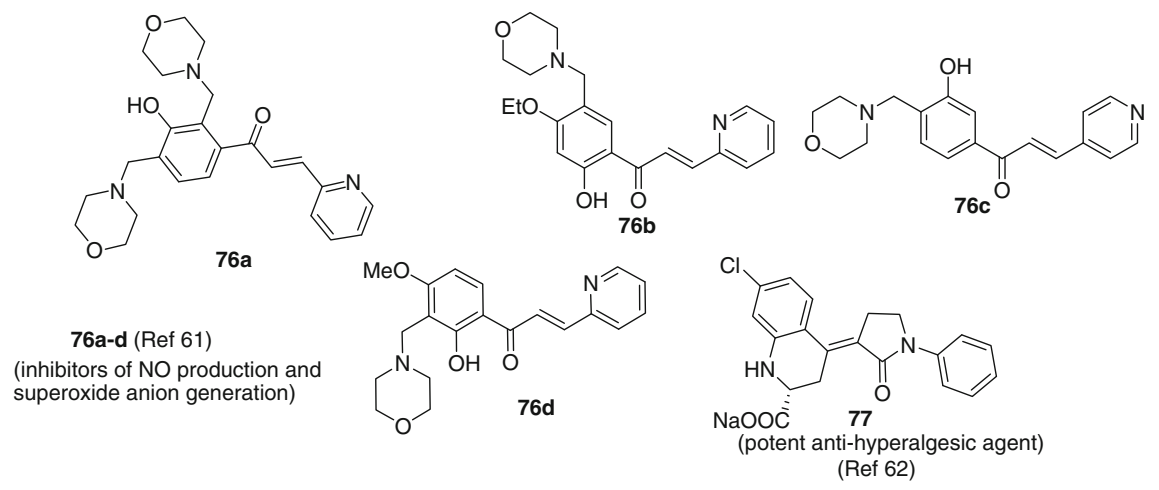

Figure 7. Antiinflammatory heterocyclic Mannich bases.<smiles></smiles>
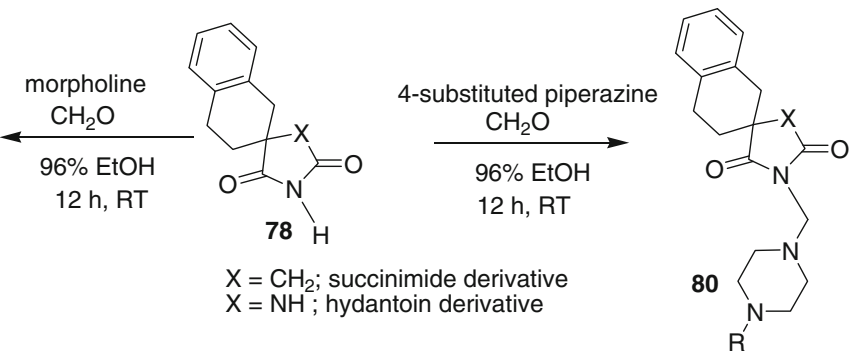

$\mathrm{R}=\mathrm{C}_{6} \mathrm{H}_{5}, 2-\mathrm{FC}_{6} \mathrm{H}_{4}, 4-\mathrm{FC}_{6} \mathrm{H}_{4}, 3-\mathrm{ClC}_{6} \mathrm{H}_{4}, 3-\mathrm{CF}_{3} \mathrm{C}_{6} \mathrm{H}_{4},-\mathrm{CH}_{2} \mathrm{C}_{6} \mathrm{H}_{5},-\left(\mathrm{CH}_{2}\right)_{2} \mathrm{OH}$

Scheme 25. Anticonvulsant Mannich bases.

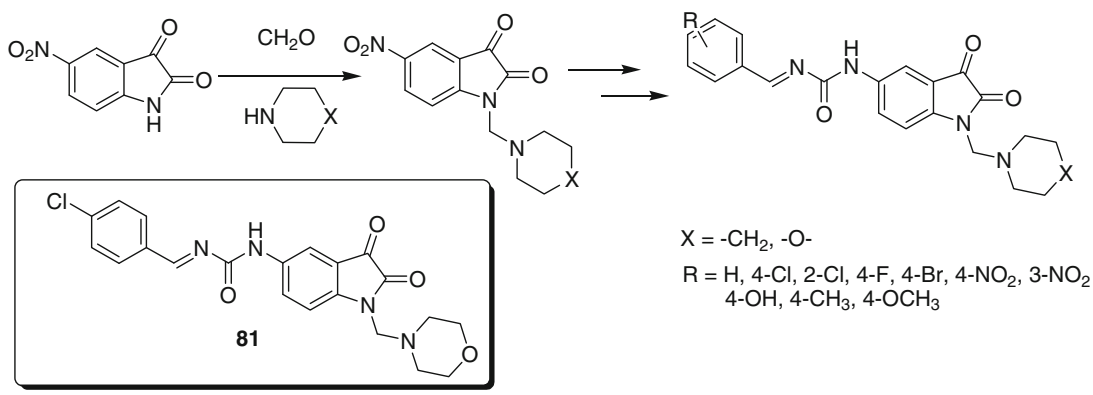

Scheme 26. Anticonvulsant urea Mannich derivatives. 
However, the parent molecule exhibited better anticonvulsant activity than the corresponding Mannich derivatives.

\section{Conclusions}

This review presents the significance of Mannich reaction and its variants in the construction of bioactive skeletons. The introduction of aminoalkyl Mannich side chain mainly used to increase the solubility, bioavailability and/or activity of the existing therapeutic/bioactive molecules such as artemisinin, topotecan, gatifloxacin, clioquinol, etc. Moreover, the Mannich derivatives are used as versatile intermediate in target synthesis of hypnotic, antiinflammatory and anticonvulsant molecules. The relative position of Mannich side chain in a molecule plays a crucial role in determining the activity of the molecule (example: Amodiaquine and Isoquine). The appropriate use of Mannich reaction and its variants offers an attractive and convenient alternate way to enhance the potency of diverse class of known therapeutic molecules.

\section{Acknowledgements}

The author is thankful to SASTRA University for providing necessary financial and infrastructural facility.

\section{References}

1. (a) Brigger I, Dubernet $\mathrm{C}$ and Couvreur P $2002 A d v$. Drug Deliver. Rev. 54 631; (b) Vauthier C, Dubernet C, Chauvierre C, Brigger I and Couvreur P 2003 J. Control. Release 93 151; (c) Tramontini M 1973 Synthesis 703

2. Mannich C and Krosche W 1912 Arch. Pharm. 250647

3. (a) Nie J, Guo H-C, Cahard D and Ma J-A 2011 Chem. Rev. 111 455; (b) Kobayashi S, Mori Y, Fossey J S and Salter M M 2011 Chem. Rev. 111 2626; (c) Candeias N R, Montalbano F, Cal P M S D and Gois P M P 2010 Chem. Rev. 110 6169; (d) Kang Y K and Kim D Y 2011 Tetrahedron Lett. 52 2356; (e) Yang Y, Phillips D P and Pan S 2011 Tetrahedron Lett. 52 1549; (f) Handa S, Gnanadesikan V, Matsunaga S and Shibasaki M 2010 J. Am. Chem. Soc. 132 4925; (g) Hashimoto T, Kimura H, Nakatsu H and Maruoka K 2011 J. Org. Chem. 76 6030; (h) Colpaert F, Mangelinckx S and Kimpe N D 2010 Org. Lett. 12 1904; (i) Shibasaki M and Kanai M 2008 Chem. Rev. 108 2853; (j) Notz W, Tanaka F, Watanabe S, Chowdari N S, Turner J M, Thayumanavan R and Barbas III C F 2003 J. Org. Chem. 689624

4. (a) Bur S K and Martin S F 2001 Tetrahedron 57 3221; (b) Martin S F 2002 Acc. Chem. Res. 35 895; (c) Liu M and Sibi M P 2002 Tetrahedron 58 7991; (d) Kobayashi S and Ishitani H 1999 Chem. Rev. 99
1069; (e) Ollevier T and Nadeau E 2007 Org. Biomol. Chem. 53126

5. (a) Arend M, Westermann B and Risch N 1998 Angew. Chem. Int. Ed. 37 1044; (b)Córdova A 2004 Acc. Chem. Res. 37 102; (c) Notz W, Tanaka F and Barbas III C F 2004 Acc. Chem. Res. 37 580; (d) Ruan S-T, Luo J-M, Du Y and Huang P-Q 2011 Org. Lett. 13 4938; (e) Ranieri B, Curti C, Battistini L, Sartori A, Pinna L, Casiraghi G and Zanardi F $2011 \mathrm{~J}$. Org. Chem. 76 10291; (f) Wang C-J, Dong X-Q, Zhang Z-H, Xue Z-Y and Teng H-L 2008 J. Am. Chem. Soc. 1308606

6. (a) Periasamy M, Ganesan S S and Suresh S 2010 Tetrahedron: Asymmetry 21 385; (b) De Graaff C, Ruijter E and Orru R V A 2012 Chem. Soc. Rev. 41 3969; (c) Periasamy M, Suresh S and Ganesan S S 2006 Tetrahedron: Asymmetry 17 1323; (d) Annunziata R, Benaglia M, Cinquini M, Cozzi F and Raimondi L 1993 Tetrahedron Lett. 34 6921; (e) Bravo P, Fustero S, Guidetti M, Volonterio A and Zanda M 1999 J. Org. Chem. 648731

7. (a) Karmakar B and Banerji J 2011 Tetrahedron Lett. 52 4957; (b) Kidwai M, Mishra N K, Bansal V, Kumar A and Mozumdar S 2009 Tetrahedron Lett. 50 1355; (c) Krishnan G R, Thomas J and Sreekumar K 2009 ARKIVOC x 106; (d) Huang P-J J, Youssef D, Cameron T S and Jha A 2008 ARKIVOC xvi 165; (e) Hayashi Y, Tsuboi W, Shoji M and Suzuki N 2003 J. Am. Chem. Soc. 125 11208; (f) Cimarelli C, Fratoni D and Palmieri G 2011 Tetrahedron: Asymmetry 221560

8. Ibrahem I, Zou W, Casas J, Sundén H and Córdova A 2006 Tetrahedron 62357

9. (a) Kumar A, Gupta M K and Kumar M 2012 Green Chem. 14 290; (b) Yang J W, Chandler C, Stadler M, Kampen D and List B 2008 Nature $\mathbf{4 5 2}$ 453; (c) Srinivas N and Bhandari K 2008 Tetrahedron Lett. 49 7070; (d) Indumathi S, Perumal S and Menéndez J C 2011 Tetrahedron 67 7101; (e) Schulz K, Ratjen L and Martens J 2011 Tetrahedron 67 546; (f) Indumathi S, Perumal S, Banerjee D, Yogeeswari P and Sriram D 2009 Eur. J. Med. Chem. 44 4978; (g) Veverková E, Štrasserová J, Šebesta R and Toma Š 2010 Tetrahedron: Asymmetry $\mathbf{2 1} 58$

10. (a) Jiang C, Zhong F and Lu Y 2012 Beilstein J. Org. Chem. 8 1279; (b) Kang Y K and Kim D Y 2009 J. Org. Chem. 74 5734; (c) Zhang Z -W, Lu G, Chen MM, Lin N, Li Y-B, Hayashi T and Chan A S C 2010 Tetrahedron: Asymmetry 21 1715; (d) Bai S, Liang X, Song B, Bhadury P S, Hu D and Yang S 2011 Tetrahedron: Asymmetry 22 518; (e) Goswami P and Das B 2009 Tetrahedron Lett. 50 2384; (f) Wu C, Fu X and Li S 2011 Tetrahedron: Asymmetry 22 1063; (g) Wu C, Fu X, Ma X, Li S and Li C 2010 Tetrahedron Lett. 515775

11. Fu A, Li H, Si H, Yuan S and Duan Y 2008 Tetrahedron: Asymmetry 192285

12. (a) Verkade J M M, van Hemert L J C, Quaedflieg P J L M and Rutjes F P J T 2008 Chem. Soc. Rev. 37 29; (b) Panday S K 2011 Tetrahedron: Asymmetry 22 1817; (c) List B 2002 Tetrahedron 58 5573; (d) Gaunt M J, Johansson C C C, McNally A and Vo N T 2007 Drug Discov. Today 12 8; (e) Pellissier H 2007 Tetrahedron 63 9267 
13. (a) Werder M, Hauser H and Carreira E M 2005 J. Med. Chem. 48 6035; (b) Roers R and Verdine G L 2001 Tetrahedron Lett. 42 3563; (c) Nicolaou K C, Dai W -M and Guy R K 1994 Angew. Chem. Int. Ed. 33 15; (d) Cardillo G and Tomasini C 1996 Chem. Soc. Rev. 25117

14. Sarhan A E-W A O, Abdel-Hafez S H, El-Sherief H and Aboel-Fadl T 2006 Synthetic Commun. 36987

15. Lal B, Gund V G, Bhise N B and Gangopadhyay A K 2004 Bioorg. Med. Chem. 121751

16. Sumalatha Y, Reddy P P, Reddy R and Satyanarayana B 2009 ARKIVOC vii 143

17. Negm N A, Morsy S M I and Said M M 2005 Bioorg. Med. Chem. 135921

18. Ferlin M G, Chiarelotto G, Antonucci F, Caparrotta L and Froldi G 2002 Eur. J. Med. Chem. 37427

19. Holla B S, Veerendra B, Shivananda M K and Poojary B 2003 Eur. J. Med. Chem. 38759

20. Malinka W, Świątek P, Filipek B, Sapa J, Jezierska A and Koll A 2005 Il Farmaco 60961

21. Baramee A, Coppin A, Mortuaire M, Pelinski L, Tomavo S and Brocard J 2006 Bioorg. Med. Chem. 14 1294

22. Chernov S V, Shults E E, Shakirov M M, Bagrjanskaja I Y, Gatilov Y V and Tolstikov G A 2003 ARKIVOC xiii 172

23. Martin S F and Bur S K 1999 Tetrahedron 558905

24. Hayashi Y, Urushima T, Shin M and Shoji M 2005 Tetrahedron 6111393

25. Babu T H, Rao V R S, Tiwari A K, Babu K S, Srinivas P V, Ali A Z and Rao J M 2008 Bioorg. Med. Chem. Lett. 181659

26. Kotecka B M, Barlin G B, Edstein M D and Rieckmann K H 1997 Antimicrob. Agents Ch. 411369 and references cited therein

27. Pacorel B, Leung S C, Stachulski A V, Davies J, Vivas L, Lander H, Ward S A, Kaiser M, Brun R and O'Neill P M 2010 J. Med. Chem. 53633 and references cited therein

28. Chipeleme A, Gut J, Rosenthal P J and Chibale K 2007 Bioorg. Med. Chem. 15273 and references cited therein

29. Guantai E M, Ncokazi K, Egan T J, Gut J, Rosenthal P J, Bhampidipati R, Kopinathan A, Smith P J and Chibale K 2011 J. Med. Chem. 543637 and references cited therein

30. O'Neill P M, Mukhtar A, Stocks P A, Randle L E, Hindley S, Ward S A, Storr R C, Bickley J F, O'Neil I A, Maggs J L, Hughes R H, Winstanley P A, Bray P G and Park B K 2003 J. Med. Chem. 464933

31. Lopes F, Capela R, Gonçaves J O, Horton P N, Hursthouse M B, Iley J, Casimiro C M, Bom J and Moreira R 2004 Tetrahedron Lett. 457663

32. Saha C N, Bhattacharya S and Chetia D 2009 Int. J. ChemTech Res. 1322

33. (a) Wenzel N I, Chavain N, Wang Y, Friebolin W, Maes L, Pradines B, Lanzer M, Yardley V, Brun R, HeroldMende C, Biot C, Tóth K and Davioud-Charvet E 2010 J. Med. Chem. 53 3214; (b) Miroshnikova O V, Hudson T H, Gerena L, Kyle D E and Lin A J 2007 J. Med. Chem. 50889

34. (a) Shchekotikhin A E, Shtil A A, Luzikov Y N, Bobrysheva T V, Buyanov V N and Preobrazhenskaya M N 2005 Bioorg. Med. Chem. 13 2285; (b) Kearney A S, Patel K and Palepu N R 1996 Int. J. Pharm. 127 229; (c) Yogeeswari P, Sriram D, Kavya R and Tiwari S 2005
Biomed. Pharmacother. 59 501; (d) Gul H I, Vepsalainen J, Gul M, Erciyas E and Hanninen O 2000 Pharm. Acta. Helv. 74 393; (e)Yamakawa T, Ideue E, Iwaki Y, Sato A, Tokuyama H, Shimokawa J and Fukuyama T 2011 Tetrahedron 676547

35. Shaw A Y, Chang C-Y, Hsu M-Y, Lu P-J, Yang C-N, Chen H-L, Lo C-W, Shiau C-W and Chern M-K 2010 Eur. J. Med. Chem. 452860

36. Chen H-L, Chang C-Y, Lee H-T, Lin H-H, Lu P-J, Yang C-N, Shiau C-W and Shaw A Y 2009 Bioorg. Med. Chem. 177239 and references cited therein

37. Euzébio F P G, Santos F J L D, Piló-Veloso D, Alcântara A F C, Ruiz A L T G, Carvalho J E, Foglio M A, Ferreira-Alves D L and Fátima A 2010 Bioorg. Med. Chem. 188172

38. Longshaw A I, Adanitsch F, Gutierrez J A, Evans G B, Tyler P C and Schramm V L 2010 J. Med. Chem. 53 6730

39. (a) Wang Z, Shi X-H, Wang J, Zhou T, Xu Y-Z, Huang T-T, Li Y-F, Zhao Y-L, Yang L, Yang S-Y, Yu L-T and Wei Y-Q 2011 Bioorg. Med. Chem. Lett. 21 1097; (b) Yoshida M, Hayakawa I, Hayashi N, Agatsuma T, Oda Y, Tanzawa F, Iwasaki S, Koyama K, Furukawa H, Kurakata S and Sugano Y 2005 Bioorg. Med. Chem. Lett. 153328

40. (a) Kumbhare R M, Kumar K V, Ramaiah M J, Dadmal T, Pushpavalli S N C V L, Mukhopadhyay D, Divya B, Devi T A, Kosurkar U and Pal-Bhadra M 2011 Eur. J. Med. Chem 46 4258; (b) Dake S A, Raut D S, Kharat K R, Mhaske R S, Deshmukh S U and Pawar R P 2011 Bioorg. Med. Chem. Lett. 21 2527; (c) Reddy C B, Kumar K S, Kumar M A, Reddy M V N, Krishna B S, Naveen M, Arunasree M K, Reddy C S, Raju C N and Reddy C D 2012 Eur. J. Med. Chem. 47 553; (d) Steere J A, Sampson P B and Honek J F 2002 Bioorg. Med. Chem. Lett. 12 457; (e) Jin L, Song B, Zhang G, Xu R, Zhang S, Gao X, Hu D and Yang S 2006 Bioorg. Med. Chem. Lett. 161537

41. Reddy M V B, Su C-R, Chiou W-F, Liu Y-N, Chen R YH, Bastow K F, Lee K-H and Wu T-S 2008 Bioorg. Med. Chem. 167358

42. (a) Chen Y-L, Huang S-T, Sun F-M, Chiang Y-L, Chiang C-J, Tsai C-M and Weng C-J 2011 Eur. J. Pharm. Sci. 43 188; (b) Almajan G L, Barbuceanu S F, Almajan E R, Draghici C and Saramet G 2009 Eur. J. Med. Chem. 44 3083; (c) Ashok M, Holla B S and Poojary B 2007 Eur. J. Med. Chem. 42 1095; (d) Joshi S, Khosla N, Khare D and Sharda R 2005 Bioorg. Med. Chem. Lett. 15 221; (e) Srivastava B K, Kapadnis P B, Pandya P and Lohray V B 2004 Eur. J. Med. Chem. 39 989; (f) Idhayadhulla A, Kumar R S, Nasser A J A, Selvin J and Manilal A 2011 Arabian J. Chem. doi:10.1016/j.arabjc.2010.12.025

43. Lóránd T, Kocsis B, Sohár P, Nagy G, Kispál G, Krane H-G, Schmitt H and Weckert E 2001 Eur. J. Med. Chem. 36705

44. Lóránd T, Ösz E, Kispál G, Nagy G, Weckert E, Luebbert D, Meents A, Kocsis B and Prókai L 2004 ARKIVOC vii 34

45. Singh U K, Pandeya S N, Singh A, Srivastava B K and Pandey M 2010 Int. J. Pharm. Sci. Drug Res. 2151

46. Ravichandran V, Mohan S and Kumar K S 2007 $A R K I V O C$ xiv 51 
47. Terzioğlu N, Karali N, Gürsoy A, Pannecouque C, Leysen P, Paeshuyse J, Neyts J and Clercq E D 2006 ARKIVOC i 109

48. Joshi S, Khosla N and Tiwari P 2004 Bioorg. Med. Chem. 12571

49. Karthikeyan M S, Prasad D J, Poojary B, Bhat K S, Holla B S and Kumari N S 2006 Bioorg. Med. Chem. 14 7482

50. Plech T, Wujec M, Siwek A, Kosikowska U and Malm A 2011 Eur. J. Med. Chem. 46241

51. Mazzei M, Nieddu E, Miele M, Balbi A, Ferrone M, Fermeglia M, Mazzei M T, Pricl S, Colla P L, Marongiu F, Ibba C and Loddo R 2008 Bioorg. Med. Chem. 162591

52. Panja S K, Maiti S, Drew M G B and Bandyopadhyay C 2009 Tetrahedron $\mathbf{6 5} 1276$

53. Rai U S, Isloor A M, Shetty P, Isloor N, Malladi S and Fun H-K 2010 Eur. J. Med. Chem. 456090

54. Saraswathi M, Rohini R M, Ranaprathapsingh and Nayeem N 2010 Pak. J. Pharm. Sci. 23459

55. Joshi S, Manikpuri A D and Tiwari P 2007 Bioorg. Med. Chem. Lett. 17645

56. Mete E, Gul H I, Bilginer S, Algul O, Topaloglu M E, Gulluce M and Kazaz C 2011 Molecules 164660

57. (a) Aboul-Fadl $\mathrm{T}$ and Bin-Jubair F A S 2010 Int. J. Res. Pharm. Sci. 1113 and references cited therein; (b) Tambo-ong A, Chopra S, Glaser B T, Matsuyama K, Tran T and Madrid P B 2011 Bioorg. Med. Chem. Lett. 215697
58. Parthiban P, Subalakshmi V, Balasubramanian K, Islam M N, Choi J S and Jeong Y T 2011 Bioorg. Med. Chem. Lett. 212287

59. Kumar G V S, Prasad Y R, Mallikarjuna B P and Chandrashekar S M 2010 Eur. J. Med. Chem. 45 5120

60. (a) Allison M C, Howatson A G, Torrance C J, Lee F D and Russell R I 1992 New Engl. J. Med. 327 749; (b) Duflos M, Nourrisson M-R, Brelet J, Courant J, LeBaut G, Grimaud N and Petit J-Y 2001 Eur. J. Med. Chem. 36 545; (c) Sujith K V, Rao J N, Shetty $\mathrm{P}$ and Kalluraya B 2009 Eur. J. Med. Chem. 44 3697

61. Reddy M V B, Hwang T-L, Leu Y-L, Chiou W-F and Wu T-S 2011 Bioorg. Med. Chem. 192751

62. Fabio R D, Alvaro G, Bertani B, Donati D, Pizzi D M, Gentile G, Pentassuglia G, Giacobbe S, Spada S, Ratti E, Corsi M, Quartaroli M, Barnaby R J and Vitulli G 2007 Bioorg. Med. Chem. Lett. 171176

63. Babu M, Pitchumani K and Ramesh P 2012 Bioorg. Med. Chem. Lett. 221263

64. Obniska J, Byrtus H, Kamiński K, Pawşowski M, Szczesio M and Karolak-Wojciechowska J 2010 Bioorg. Med. Chem. 186134

65. Prakash C R and Raja S 2011 Eur. J. Med. Chem. 46 6057

66. Byrtus H, Obniska J, Czopek A, Kamiński K and Pawşowski M 2011 Bioorg. Med. Chem. 196149 